\title{
MONITORING AND CONTROLLING MOULD MITES IN TISSUE CULTURE FACILITIES
}

\author{
C.W. VAN EPENHUIJSEN and J.P. KOOLAARD \\ Crop \& Food Research, Private Bag 11600, Palmerston North, New Zealand \\ Corresponding author: vanepenhuijsenk@crop.cri.nz.
}

\begin{abstract}
Mould mite numbers were successfully monitored in tissue culture laboratories using black tape where numbers of mites were high. Natural diamite and Parafilm "M" were the best barriers for preventing mould mite contamination. Treating surfaces with a miticide-containing paint (Artilin 3A) or bendiocarp prevented mites from entering containers holding food suitable for mould mites. Mites were not killed when sprayed with aerosols and $70 \%$ ethanol.
\end{abstract}

Keywords: barrier, mould mite, tissue culture, Tyrophagus putrescentiae.

\section{INTRODUCTION}

Contamination of in vitro cultures during micropropagation is often the result of fungal infections introduced by mites and insects. Blake (1988) found that $50 \%$ of tissue culture laboratories were contaminated with mites or insects at some time. While mites and thrips cause minimal damage to plant material, they may travel between culture vessels and tubs, carrying fungal spores and bacteria in and on their bodies (Jong 1987). One commonly transferred fungus, Penicillium islandicum, known as yellow rice fungus, is a human health hazard as it produces mycotoxins that cause liver lesions, cirrhosis and primary carcinoma. The fungus produces pigments that colour the substrates upon which it grows yellow or orange (M. Dance, pers. comm.).

When mould growth is caused by mite or insect contamination it is generally found growing across the entire surface of agar-filled tubs whereas a single mould spot is more likely to be due to poor aseptic techniques by operators (J. Seelye, pers. comm.). Outbreaks of mould mites (Tyrophagus spp.) usually result from the introduction of infested material (e.g. tubers or bulbs) into the laboratory. Numbers can increase 2000 fold in a single month (Anon. undated). However, permanent populations of mould mites can also occur in buildings. They may be found on stored kiwifruit and tubers, such as kumara. Although found in stored produce and dried meat they do not thrive on these diets (C.W. van Epenhuijsen, unpubl. data).

Most mites are Tyrophagus spp., such as T. perniciosus (B. Strolka, pers. comm.), although cyclamen mites (Phytonemus pallidus spp.) (George 2000) and Siteroptes avenae (Staal 1989) have been found in cultures as well. The most common mites in New Zealand are Tyrophagus putrescentiae, although T. neiswanderi (M. O'Donnell, pers. comm.) and Siteroptes avenae (N. Martin, pers. comm.) have been found in culture rooms as well as a predatory mite (Amblyseius sp.) in the microtubers of calla (Zantedeschia spp.) (M. O’Donnell, pers. comm.).

Mite control is generally achieved by adopting good hygiene measures, using mechanical and chemical barriers, fumigation, and protected storage facilities (Onions 1990). Other preventative methods include freezing all lab coats regularly and using a chemically treated doormat. Heating equipment to $40^{\circ} \mathrm{C}$ for $48 \mathrm{~h}$ completely killed mites (Pulpan \& Verner 1959). Zdarkova \& Voracek (1993) found $60 \mathrm{~min}$ at $-15^{\circ} \mathrm{C}$ produced $100 \%$ mite mortality while $30 \mathrm{~min}$ at $55^{\circ} \mathrm{C}$ or higher gave $100 \%$ mortality. Low pressure (95 $\mathrm{mm} \mathrm{Hg}$ ) gave $100 \%$ mite mortality (Zdarkova \& Voracek 1993), and a vacuum of $190 \mathrm{~mm} \mathrm{Hg}$ provided some protection to food against mites when applied at $-15^{\circ} \mathrm{C}$ or lower. Smith \& Onions (1999) found storage at $4-8^{\circ} \mathrm{C}$ reduced the activity of mites. 
However, the mites became active again as soon as the temperature increased. A temperature of $-20^{\circ} \mathrm{C}$ for at least 3 days gave better control (Smith \& Onions 1999).

For long-term cultures it is sometimes advised to dip the cotton wool vent into a miticide. However, this technique does not work with wide-mouth plastic tissue culture tubs $(290 \mathrm{ml})$, which have snap-on lids for ventilation. Another method is to place cultures on a platform that is sitting in a thin layer of mineral or cottonseed oil (Davidson \& Lyon 1979). Vaseline and silicone grease can be used but normally they are too labourintensive to apply to individual tubs and are unpleasant to use. Parafilm "M" and cigarette papers (Snyder \& Hansen 1946) are sometimes recommended as a barrier (Remakanthan 2003). However, mites have been reported to go through the film (P.S. Stewart, pers. comm.). Dipping leaves in a sodium hypochlorite solution before culturing can disinfest them of two-spotted spider mites (Tetranychus urticae) (Hadi et al. 1998).

Fungicides, such as fenbutatin oxide, or chemicals from the imidazol family can be included in the culture medium for some plants (Pype 1996; Werbrouck et al. 1999), but this does not prevent fungal contamination being introduced by mites. The insecticide acephate, Orthene ${ }^{\circledR}$, when added to the medium, killed Allothrips spp. (Klocke \& Myers 1984). A miticide with active ingredient pirimiphos-methyl is advised for use on workbenches (Smith \& Onions 1999).

This paper describes a series of experiments aimed at monitoring mite populations in tissue culture laboratories and testing methods for excluding or eliminating mould mites (Tetranychys putrescentiae) from these areas.

\section{MATERIALS AND METHODS}

\section{Rearing mites}

A mould mite population was started using mites collected from contaminated tissue culture tubs of calla plantlets. The mites were reared in a 50:50 mix of yeast and rat food (Sharpes Animal Foods Diet 86). A pinch (approximately $0.02 \mathrm{~g}$ of diet infested with mould mites) was placed with approximately $10 \mathrm{~g}$ clean diet in $70 \mathrm{ml}$ jars with $3 \mathrm{~mm}$ vents covered in fine mesh. The jars were cultured in an airtight container with moist paper towels at $27^{\circ} \mathrm{C}$ and $70-80 \%$ relative humidity (RH).

The mite-infested diet was stirred with a needle and poured through a kitchen sieve (approximately $850 \mu \mathrm{m}$ ). The sieved material (a fine dust) was stuck on $50 \mathrm{~mm}$ wide black polyethylene self-adhesive tape (Sealed Air Insultape) by rolling a $200 \mathrm{~g}$ metal piece of pipe over it. All live mites in a number of randomly chosen $7 \mathrm{~mm}$ circles (cut out of a thin aluminium sheet overlay) were counted.

All trials were assessed $24 \mathrm{~h}$ after treatment for numbers of live mites as dead mites shrivel up within a day and cannot be distinguished in the diet.

\section{Trapping and monitoring}

A mould mite trap, consisting of black-painted plastic strips $(300 \times 100 \mathrm{~mm})$ that were coated with Tangle-Trap ${ }^{\circledR}$ brush-on formula (The Tanglefoot Company, Grand Rapids, Michigan), was tested. The strip traps were placed on the floor with the sticky side up and in the racks of two tissue culture rooms, in a storage room and in the mite rearing unit. A mite lure, consisting of a $5 \mathrm{~g}$ sample of mould mite diet placed in a $15 \mathrm{ml}$ glass container, was also tested. Two traps and lures per room were checked every 3 weeks under the microscope for more than 12 months for the presence of mites. The position of the traps was changed each time. Window traps (AgriSense-BCS Ltd) were tested for their ability to catch mites.

\section{Barrier tests}

Potential barriers for mites were tested using two covered acrylic cages $(690 \mathrm{x} 400 \mathrm{x}$ $410 \mathrm{~mm}$ ) held at $27^{\circ} \mathrm{C}$ and $70 \% \mathrm{RH}$. The cages contained glass jars (50 ml, diameter 50 $\mathrm{mm}$ and filled with $6 \mathrm{ml} \mathrm{diet)} \mathrm{that} \mathrm{had} \mathrm{been} \mathrm{given} \mathrm{one} \mathrm{of} \mathrm{ten} \mathrm{treatments.} \mathrm{The} \mathrm{cages} \mathrm{had}$ a Tangle-Trap ${ }^{\circledR}$ band around the circumference of the cage to prevent mites reaching the lid and dropping into the jars from above. There were 6 replicate jars of each treatment except the untreated control ( 7 jars), fluon (5 jars) and diamite (5 jars), which were randomly placed throughout the two cages. 
The treatments were:

- untreated control

- Tangle-Trap ${ }^{\circledR}$

- Vaseline (Petroleum jelly BP, Amcam Chemists Marketing Ltd) applied as a $15 \mathrm{~mm}$ band brushed on to the bottom of the jar

- Fluon (Fluon AD-1, an aqueous dispersion of polytetrafluoethylene) applied as a $15 \mathrm{~mm}$ band brushed on to the bottom of the jar

- Glycerol BP poured into an $85 \mathrm{~mm}$ Petri dish in a thin layer and the jar placed in the Petri dish

- kerosene $(100 \%)$ poured into an $85 \mathrm{~mm}$ Petri dish in a thin layer and the jar placed in the Petri dish

- $\quad$ machinery oil (3-in-one, Home Products NZ Ltd) poured into an $85 \mathrm{~mm}$ Petri dish in a thin layer and the jar placed in the Petri dish

- natural diamite (DPL 13, ex New Zealand), a diatomaceous earth sieved through $500 \mu \mathrm{m}$ and spread as a thin layer into an $85 \mathrm{~mm}$ Petri dish, and the jar placed in the Petri dish

- Parafilm "M" (American National Can ${ }^{\mathrm{TM}}$ ), a laboratory plastic wrap, stretched over the top of loosely screwed Bakelite lids on top of the glass jar

- Artilin 3A, a miticide-containing paint, brushed on to undercoated wooden disks (diameter $80 \mathrm{~mm}$ ).

Eighteen small lids (diameter $45 \mathrm{~mm}$ ) with infested diet were placed at random between the treated jars in each cage. A glass jar with a paper wick filled with water kept the humidity in the cages higher than $78 \%$. All mites were counted in 6 randomly chosen circles of $7 \mathrm{~mm}$ diameter of the diet per jar after 5 weeks.

\section{Tunnel trial}

Plastic pipes, $350 \mathrm{~mm}$ long with an internal diameter of $17 \mathrm{~mm}$, were cut open longitudinally and covered on the inside with the pesticides artilin, fentabutin (Ficam ${ }^{\circledR}$ W) or left untreated. Ficam ${ }^{\circledR} \mathrm{W}$ is a carbamate containing $800 \mathrm{~g} / \mathrm{kg}$ bendiocarb. It is a registered public health miticide in New Zealand. There were 6 pipes for each pesticide and the control. The slits in the pipes were closed with tape.

One end of each pipe was attached with a sealant (No More Gaps, Selleys Pty Ltd) at random into holes cut in the side of a 5 litre plastic bucket. Pipes were $40 \mathrm{~mm}$ from each other and $50 \mathrm{~mm}$ from the bottom radiating out horizontally. At the other end of the pipe, outside of the bucket, a $70 \mathrm{ml}$ specimen jar was attached with the sealant, filled with $15 \mathrm{ml}$ of clean diet and placed at $27^{\circ} \mathrm{C}$. A heavily infested diet with mites was placed in the bucket with some damp paper towel and the bucket was closed. The diet in the specimen jar was sieved onto a black tape 18 days later and the number of mites in four circles per specimen jar was counted. The number of live mites on the total area of the black tape (approximately $50 \mathrm{~cm}^{2}$ ) was counted if no mites were found in the four randomly chosen circles.

\section{Overhead spraying}

A highly infested mite diet (approximately $1.5 \mathrm{~g}$ ) was sieved through a small kitchen sieve into a Petri dish and sprayed with one of three aerosols, $70 \%$ ethanol or a distilled water mist control for 4 seconds. Ethanol and water were sprayed with a low-pressure household sprayer. The three aerosols were:

- CheckMite, a herbal aerosol for the control of indoor allergens from Dermatophagoides spp.

- 'Raid fast kill odourless hypoallergenic' containing $1.54 \mathrm{~g} / \mathrm{kg}$ tetramethrin, $0.34 \mathrm{~g} / \mathrm{kg}$ d-phenothrin and $0.34 \mathrm{~g} / \mathrm{kg}$ d-allethrin

- 'Raid multipurpose insect killer' containing $4.0 \mathrm{~g} / \mathrm{kg}$ tetramethrin and $1.0 \mathrm{~g} / \mathrm{kg}$ permethrin

Water-sensitive paper (Spraying Systems Co., USA) laid between the Petri dishes was used to verify that the cover applied over the treatments was the same. Petri dishes were covered for $15 \mathrm{~min}$ after treatment; thereafter the diet was poured into a $70 \mathrm{ml}$ jar, closed and kept at $27^{\circ} \mathrm{C}$ for one day. The diet was then sieved onto a black tape as 
described previously. Four replicates of four areas of randomly chosen circles on the black tape were assessed for live mites.

\section{Trapping and monitoring}

\section{RESULTS}

When mould mites escaped from the containers in the rearing unit they were caught on the Tangle-Trap ${ }^{\circledR}$ coated strips or lured into baits. No mites were found in the traps in the cell culture rooms. Dried bodies of mites and other insects were found on the strips in the cell culture rooms. Mites were caught on tape stuck on the bench where a contaminated tuber had been laid. Tape samples taken at random and assessed under a microscope gave a good indication of whether mites (or dried skins) were present in the rooms. Window traps (AgriSense-BCS Ltd) also successfully detected mites, but the brown background made it too difficult to locate them.

\section{Barriers}

There were significantly $(\mathrm{P}<0.05)$ fewer mites in jars that were 'protected' with Parafilm "M", natural diamite, machinery oil and Tangle-Trap ${ }^{\circledR}$ compared to levels found in the control jars (Fig. 1). Dead mites were found on the treated disks of artilin but the barrier was probably not wide enough to kill all mites. The layer of kerosene crystallised quickly and mites were able to walk over it to the diets.

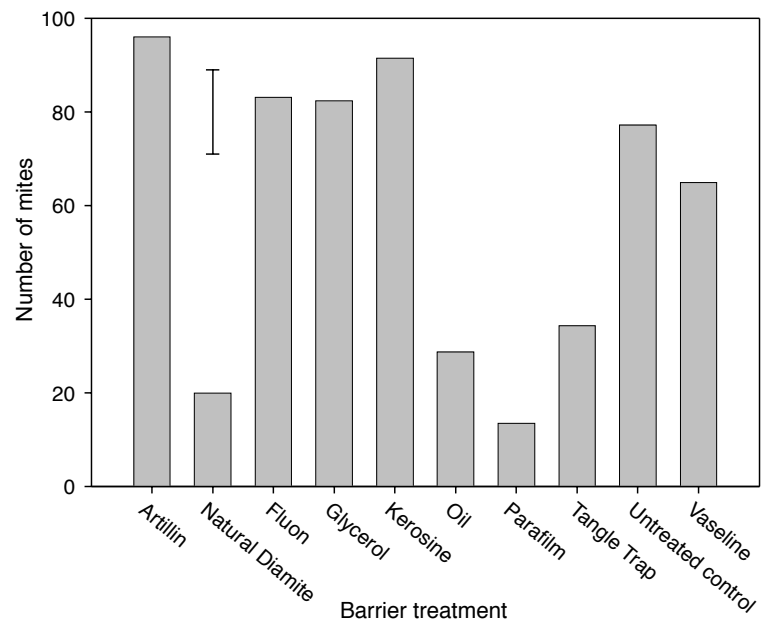

FIGURE 1: The number of mites entering glass jars given various barrier treatments. The bar indicating the $\operatorname{LSD}(\mathrm{P}=0.05)$ is 17.98 units.

\section{Tunnel trial}

The number of live mites in the untreated control was very high (Table 1). No mites were found in the artilin treatment. A few mites were found in the Ficam ${ }^{\circledR} \mathrm{W}$ when extra counts were made. Dead mites were found as brown clusters of dust in the treated pipes. Overhead spraying

There was no evidence of a difference in efficacy between any of the three aerosols or ethanol treatments and the water mist control (data not shown). 
TABLE 1: Number of mites found on 24 disk areas from samples taken from the jars at the end of plastic pipes.

\begin{tabular}{ll}
\hline Treatment & Number of mites \\
\hline Untreated $_{\text {Ficam }}^{\circledR} \mathrm{W}(0.3 \%)$ & 88.17 \\
Artilin 3A & $0.00(0.67)^{1}$ \\
\hline
\end{tabular}

${ }^{1}$ Mites found in the remaining diet on the tape.

\section{DISCUSSION}

Mites are a problem in tissue culture laboratories because they are a common source of contamination and their numbers can increase very rapidly. The trapping and monitoring techniques described in this paper worked well if mite numbers were high. Sticky black tape on the benches successfully monitored mite infestations of calla tubers, catching up to 10 mites on a $50 \mathrm{~cm}^{2}$ tape. Bait (mite diet) and Tangle-Trap ${ }^{\circledR}$ covered strips can detect mites. The sprays tested were not effective. Results suggest that hygiene measures and establishing barriers to mite infestation are the most promising methods of control.

These trials suggest that coating laboratory floors with Ficam or painting walls with artilin (which kills both mites and larvae) may provide effective control for up to 3 years (C. Ricard, pers. comm.). Alternatively, putting the legs of benches in diatomite may provide some control. However, it is important that the ability to clean floors is retained because mites breed in dust. Our observations suggest that commonly recommended barriers, such as water, glycerol and eucalyptus paste, are not effective.

Barriers and other measures used to prevent mites from entering tubs were not $100 \%$ effective. Mould mite nymphs can pass through very small holes; early stages passed through 120/120 wire mesh and 3M Micropore ${ }^{\mathrm{TM}}$ Tape, cigarette and pipette filters, loose foam and cottonwool closures (C.W. van Epenhuijsen, unpubl. data). Vented vessels from Gaooze (Korean Scientific Technique Industry) using the $3 \mathrm{M}$ Micropore ${ }^{\mathrm{TM}}$ did not exclude mites. Mites also may traverse taped areas by passing through the channel where the tape overlaps. A similar problem can occur with plastic cling film as the surface of the flasks might be uneven allowing mites to enter.

Maintaining high hygiene standards is important because plant material is the main source of contamination in culture rooms. Hot water treatment of infested tubers has produced disinfested plant material, but microwaving is ineffective since the agar and plastic tubs melt before mites are killed (C.W. van Epenhuijsen, unpubl. data).

In conclusion, many barriers and control methods are ineffective. It is recommend that before plant material is placed in tissue culture rooms it is disinfested. In addition, walls in tissue culture rooms could be painted with artlilin paint.

\section{ACKNOWLEDGEMENTS}

The authors would like to thank Mrs Carine Boisserie of Functional Paints (France) for supplying the Artilin paint. Mike Goss of Genera Ltd supplied us with Ficam W. Natural diatomite was supplied by Diatomite Products Ltd (New Zealand), and CheckMite was supplied by Vittal Mallya Scientific Research Foundation, Bangalore, India. Mike Dance (AgriQuality New Zealand) did the identification and provided information on Penicillium.

\section{REFERENCES}

Anon. 2001: Artilin 3A Anti-dust mites paints. Artilin Functional Paints. B.P.12. 47450 Colayrac Saint-Cirq, France. 6 p.

Anon. undated: How do you know if you have a mite problem? Central Science laboratory. York, UK. 
Blake, J. 1988: Mites and thrips as bacterial and fungal vectors between plant tissue cultures. Acta Hort. 225: 163-166.

Davidson, R.H.; Lyon, W.F. 1979: Insect pests of farm, garden and orchard. John Wiley $\&$ Sons. New York. 596 p.

George, S. 2000: http://www.ago.agri.umn.edu.plant-tc/listserv/2000/logooio/ msgooo85.html. 27/08/02.

Hadi, M.Z.; Bridgen, M.P.; Sanderson, J.P. 1998: Establishment of tetranychid mites in vitro. HortTech. 8(2):179-182.

Jong, S.C. 1987: Prevention and control of mite infestations in fungus cultures. American type Culture collection (ATCC). Quarterly Newsletter 7(1): 1 and 7.

Klocke, J.A.; Myers, P. 1984: Chemical control of thrips on cultured Simmondsia chinensis Jojoba shoots. HortSci. 19(3): 400.

Lyon, W.F. 1991: Mites infesting stored foods. HYG-2152-97. Ohio State University Extension Fact Sheet, Entomology. http://ohioline.ose.edu/hyg.fact 2000/2156.html.

Mulcahy, R. 1987: Artilin 3A paint against adults and eggs of the house dust mite Dermatophagoides pteronyssinus. A report by the medical Entomology Centre at the University of Cambridge, U.K. 7 p.

Onions, A.H.S. 1990: Prevention of mites in cultures. World J. Microbiol. Biotechnol. Technical Information Sheet No. 16: 219-221.

Pulpan, J.; Verner, P. 1959: Roztoci zijici na uskladnemen obili a boj proti num (Acari). Bohemia Centralis 1: 1-292 (In Czech, German res.).

Pype, J. 1996: Control of arthropod contamination. International Symposium on bacterial and bacterial-like contaminants of plant tissue cultures. Cork (Ireland). Agricel report 27(4): 29.

Remakanthan, N. 2003: Plant-tc Monthly Archive.. http://plant-tc.coafes.umn.edu/ listserv/2003/log0303/msg00166.html. 12/03/04

Smith, D.; Onions, A.H.S. 1999: The preservation and maintenance of living fungi. $2^{\text {nd }}$ ed. IMI Technical Handbook No. 2. CAB International Wallingford, U.K. 122 p.

Snyder, W.C.; Hansen, H.N. 1946: Control of mites by cigarette paper barriers. Mycologia 38: 455-562.

Staal, G.B. 1989: The mite and the mold. Pleurothallid Alliance News 1: 4,1,5.

Werbrouck, S.; Goethals, K.; Van Montagu, M.; Debergh, P. 1999: Surprising micro propagation tools. In: Altman, A. ed. Plant iotechnology and in vitro biology in the $21^{\text {st }}$ century. Kluwer Academic Publishers. Pp. 667-672.

Zdarkova, E.; Voracek, V. 1993: The effects of physical factors on survival of stored food mites. Exp. \& Appl. Acarol. 7: 197-204. 